\title{
Male Meiotic Studies in Six Species of Pedicularis L. from Churdhar and Adjoining Hills of Sirmaur District (H. P.), India
}

\author{
Vijay Singh ${ }^{1,2 *}$, Raghbir Chand Gupta ${ }^{2}$, Kuljit Kaur ${ }^{1,2}$, \\ Ramesh Chand Kataria ${ }^{3}$ and Ravindra Kumar ${ }^{4}$

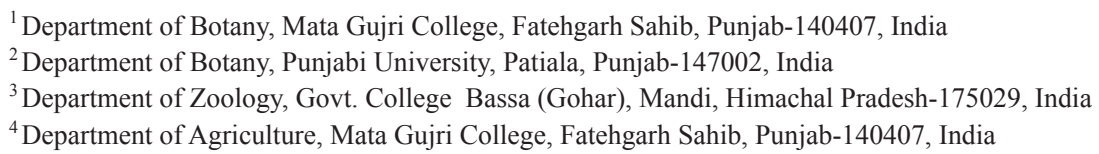

Received December 31, 2018; accepted April 7, 2019

\begin{abstract}
Summary The genus Pedicularis L. comprises many medicinal species in Sirmaur district of Himachal Pradesh, the Northwest Himalayan range. In the present study, male meiotic studies have been carried out in six species of the genus and revealed $n=8$ chromosome number in all taxa. The chromosome number $(n=8)$ in $P$. heterodonta and $P$. punctata are new to the world, while $P$. oederi reveals the first chromosome report for Indian populations. Besides, a B chromosome and structural heterozygosity were reported for the first time in $P$. hoffmeisteri and $P$. pectinata, respectively. Further, meiotic anomalies, like chromatin bridges, interbivalent connections, laggards, un-even gamete formation and reduce pollen viability, were also observed in the studied populations.
\end{abstract}

Key words Chromosome number, Meiotic abnormality, Pedicularis, Sirmaur district.

The genus Pedicularis L. known popularly as lousewort, belongs to the family Orobanchaceae and comprises about 600 species in alpine and sub-alpine or even in the tundra regions of the northern hemisphere. In India, the maximum diversity of the genus is found in Himalayan range with 81 species, ranging Ladhakh to Arunachal Pradesh in east covering Sikkim Himalayas (Yatoo et al. 2016). Terminal inflorescences, forked calyx in the anterior end and typical bi-labiate corolla (larger ventral lobes than dorsal) having a hooded upper lip, are few peculiar characteristics of the genus.

In the modern era, due to emerging drug resistance, herbal medicines, due to their multiple beneficial health applications and as an alternative, are gaining increased attention among researchers at global stage (Ganjhu et al. 2015). The species of Pedicularis are rich in alkaloids, flavonoids, iridoids, lignans, polyphenols, and other phytochemicals (Khodaie et al. 2012, Zhao et al. 2013, Mura and Iwashina 2015). Several phytochemical extracts of the species are reported to treat various diseases and disorders that include general clinical conditions, various ailments or even in maintaining vitality (Chu et al. 2009, Yatoo et al. 2016, 2017). The quantitative and qualitative measures of these compounds, generally believed to vary in cyto/morpho/ecotypes. Further, cytogenetics is considered among the key determinants in studying evolutionary concepts in plants owing to meiotic anomalies (Singh et al. 2016). Thus,

*Corresponding author, e-mail: vijaykataria05@rediffmail.com DOI: $10.1508 /$ cytologia. 84.233 the present meiotic study will be informative in making chromosomal databases and evolutional concepts, and even in developing effective medicines and nutraceutical products.

\section{Materials and methods}

Eight populations of six species Pedicularis (54 individuals) have been collected from various localities of Sirmaur district of Himachal Pradesh in India (Table 1) and studied cytologically. The voucher specimens were submitted in the Herbarium of Botany Department, Punjabi University, Patiala (PUN). For meiotic studies, the young floral buds were fixed in a freshly prepared Carnoy's fixative (ethanol, chloroform, glacial acetic acid in $6: 3: 1$ ) for $24 \mathrm{~h}$, which were transferred to $70 \%$ alcohol and stored in a refrigerator at $4{ }^{\circ} \mathrm{C}$. Meiotic slides were prepared by a squashing the fixed anthers in $1 \%$ acetocarmine. The chromosome number was determined by analyzing 300-350 pollen mother cells (PMCs) at different countable stages of meiosis [metaphase I, II (M I, II) and anaphase I, II (A I, II)] under a microscope and then photomicrographs of detailed meiosis and microsporogenesis were taken with a digital imaging system of Leica QWin DM3400. Pollen viability was analyzed on mature pollens after heating in glycerol-acetocarmine $(1: 1)$ for $24 \mathrm{~h}$. More than 250 pollen grains were studied for pollen viability and size variability. The fully-filled pollen grains with stained nuclei were considered as fertile, while shriveled and unstained as sterile. 
Table 1. Table showing details regarding the name of species, a locality with an altitude, chromosome number, ploidy leve, size of pollen grains, and remarks on the meiotic course of previous worked out species.

\begin{tabular}{|c|c|c|c|c|c|}
\hline $\begin{array}{l}\text { Name of species, plant number, } \\
\text { voucher number (PUN) }\end{array}$ & $\begin{array}{c}\text { Locality, altitude in meters, } \\
\text { geographical co-ordinates }\end{array}$ & $\begin{array}{l}\text { Chromosome number } \\
(n)\end{array}$ & $\begin{array}{l}\text { Ploidy level } \\
\qquad(x)\end{array}$ & $\begin{array}{l}\text { Pollen size } \\
(\mu \mathrm{m} \pm \mathrm{SD})\end{array}$ & $\begin{array}{l}\text { Pollen number viability } \\
\qquad(\%)\end{array}$ \\
\hline \multicolumn{6}{|l|}{ P. gracilis Wall. ex Benth. } \\
\hline P-1 60053 & $\begin{array}{l}\text { Churdhar, } 3650 \\
30^{\circ} 52^{\prime} \mathrm{N}, 77^{\circ} 28^{\prime} \mathrm{E}\end{array}$ & 8 & 2 & $30.6 \pm 0.4 \times 32.5 \pm 1.2$ & 85 \\
\hline \multicolumn{6}{|l|}{ P. heterodonta Pancic ex Janka } \\
\hline P-1 59664 & $\begin{array}{l}\text { Churdhar, } 3650, \\
30^{\circ} 52^{\prime} \mathrm{N}, 77^{\circ} 28^{\prime} \mathrm{E}\end{array}$ & 8 & 2 & $\begin{array}{l}s-12.5 \pm 0.2 \times 14.2 \pm 0.9 \\
l-22.5 \pm 1.1 \times 25.3 \pm 1.3\end{array}$ & 65 \\
\hline 60054 & $\begin{array}{c}\text { Tisri, } 3650 \\
30^{\circ} 51^{\prime} \mathrm{N}, 77^{\circ} 27^{\prime} \mathrm{E}\end{array}$ & 8 & 2 & $\begin{array}{l}s-11.6 \pm 0.4 \times 13.9 \pm 0.6 \\
l-20.9 \pm 1.2 \times 23.8 \pm 1.4\end{array}$ & 61 \\
\hline \multicolumn{6}{|l|}{ P. hoffmeisteri Klotzsch } \\
\hline P-1 58623 & $\begin{array}{l}\text { Churdhar, } 3650, \\
30^{\circ} 52^{\prime} \mathrm{N}, 77^{\circ} 28^{\prime} \mathrm{E}\end{array}$ & $8+0-1 B$ & 2 & $\begin{array}{l}s-12.6 \pm 0.3 \times 13.6 \pm 0.9 \\
l-22.9 \pm 0.9 \times 24.0 \pm 1.0\end{array}$ & 58 \\
\hline \multicolumn{6}{|l|}{ P. oederi Vahl } \\
\hline $\begin{array}{ll}\text { P-1 } & 59502\end{array}$ & $\begin{array}{l}\text { Churdhar, } 3650, \\
30^{\circ} 52^{\prime} \mathrm{N}, 77^{\circ} 28^{\prime} \mathrm{E}\end{array}$ & 8 & 2 & $\begin{array}{l}s-12.6 \pm 0.5 \times 13.6 \pm 0.5 \\
l-22.9 \pm 1.3 \times 24.0 \pm 1.3\end{array}$ & 65 \\
\hline 60050 & $\begin{array}{c}\text { Jamnala, } 3650 \\
30^{\circ} 50^{\prime} \mathrm{N}, 77^{\circ} 26^{\prime} \mathrm{E}\end{array}$ & 8 & 2 & $\begin{array}{l}s-10.2 \pm 0.2 \times 12.1 \pm 0.5 \\
l-23.4 \pm 1.3 \times 27.5 \pm 1.6\end{array}$ & 65 \\
\hline \multicolumn{6}{|l|}{ P. pectinata Wall. ex Benth. } \\
\hline P-1 $\quad 59784$ & $\begin{array}{l}\text { Churdhar, } 3650, \\
30^{\circ} 52^{\prime} \mathrm{N}, 77^{\circ} 28^{\prime} \mathrm{E}\end{array}$ & 8 & 2 & $23.9 \pm 1.5 \times 25.6 \pm 1.6$ & 79 \\
\hline 60055 & $\begin{array}{l}\text { Chapdhar, } 3650 \text {, } \\
30^{\circ} 49^{\prime} \mathrm{N}, 77^{\circ} 25^{\prime} \mathrm{E}\end{array}$ & 8 & 2 & $24.3 \pm 1.6 \times 26.4 \pm 2.1$ & 76 \\
\hline \multicolumn{6}{|l|}{ P. punctata Decne. } \\
\hline P-1 58622 & $\begin{array}{l}\text { Nauradhar, } 3650 \text {, } \\
30^{\circ} 48^{\prime} \mathrm{N}, 77^{\circ} 25^{\prime} \mathrm{E}\end{array}$ & 8 & 2 & $\begin{array}{l}s-14.6 \pm 0.5 \times 15.0 \pm 0.4 \\
l-20.6 \pm 1.4 \times 23.1 \pm 2.3\end{array}$ & 65 \\
\hline
\end{tabular}

$s$-small pollen grain, $l$-large pollen grain, $\mu=$ mean, $\mathrm{SD}=$ Standard deviation.

Results and discussion

\section{Chromosome numbers}

P. gracilis showed $n=8$ in the PMCs (Fig. 1A), and this count confirms the previous reports (Mehra and Gill 1968, Amano 1999).

P. heterodonta revealed $n=8$ at M I (Fig. 1B), which is the first chromosome report.

P. hoffmeisteri showed B chromosome (Fig. 1C). Previously, the species is reported with $2 n=16$ by Saggoo and Srivastva (2009) from Lahaul-Spiti district of Himachal Pradesh (2009) and Amano (1999) from Nepal. Due to the presence of B chromosome, the meiotic abnormalities in the species are low compared to the others (Table 2), which resemble many previous studies (Houben 2017).

$P$. oederi reveals the first chromosome number of $n=8$ (Fig. 1D) from India (Singh et al. 2016). Earlier, the species is reported with the same chromosome number $(2 n=16)$ from the Furkotská dolina valley of Slovakia (Uhríková and Dúbravcová 2000).

P. pectinata showed $n=8$ (Fig. 1E) and the chromosome number supports the previous report by Saggoo and Srivastava (2009). The species reveals structural heterozygosity (Fig. 1E), the quadrivalent/s in PMCs at $\mathrm{M} \mathrm{I}$, are thought to arise due to partial homology in nonhomologous pairs that forms an association in the form of reciprocal translocations. The similar phenomenon has been discussed in genera, like Oenothera, Datura,

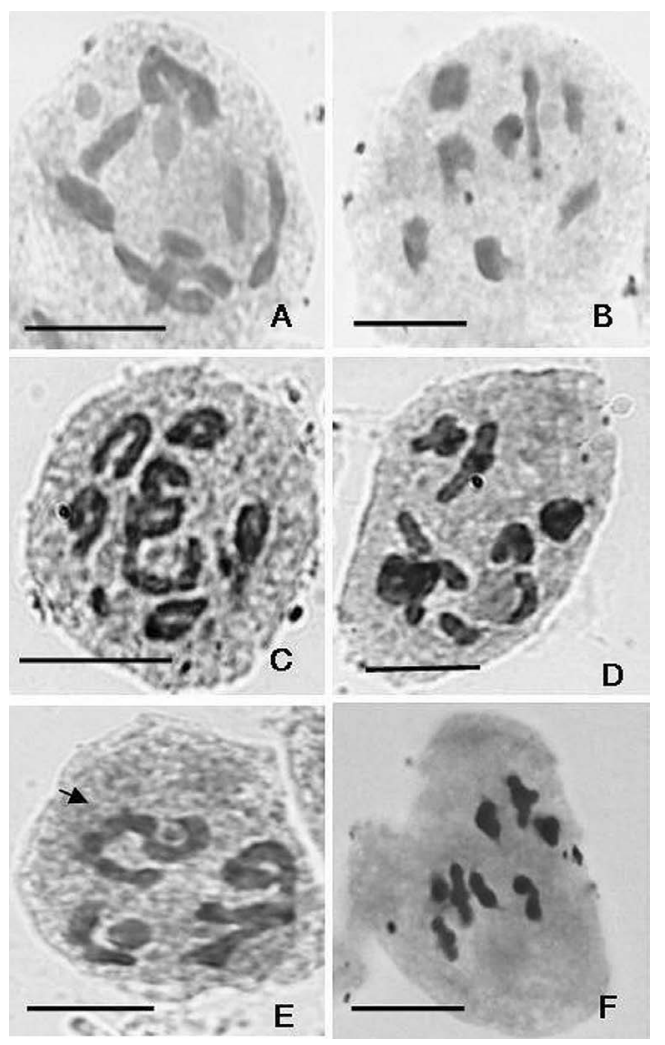

Fig. 1. A PMC with $8_{\mathrm{II}}$ at diakinesis in P. gracilis (A), a PMC showing $8_{\mathrm{II}}$ at $\mathrm{M} \mathrm{I}$ in $P$. heterodonta (B), a PMC with $8_{\mathrm{II}}+1 \mathrm{~B}$ (arrowed) at M I in P. hoffmeisteri (C), a PMC at diakinesis showing $8_{\mathrm{II}}$ in $P$. oederi (D), a PMC showing $1_{\mathrm{IV}}+6_{\mathrm{II}}$ configuration (arrowed) at M I in P. pectinata (E), a PMC with $8_{\mathrm{II}}$ at M I in $P$. punctata (F). Scale bars $=10 \mu \mathrm{m}$. 
Table 2. Data on the meiotic course in the studied populations of six species of Pedicularis from Churdhar and adjoining hills of Sirmaur (H.P.).

\begin{tabular}{|c|c|c|c|c|}
\hline Plant number & $\begin{array}{l}\text { PMCs with chromosomal } \\
\text { stickiness at M I (\%) }\end{array}$ & $\begin{array}{l}\text { PMCs with unoriented } \\
\text { bivalents at M I (\%) }\end{array}$ & $\begin{array}{l}\text { PMCs with bridges } \\
\text { (at A I/T I) }(\%)\end{array}$ & $\begin{array}{c}\text { PMCs with laggards } \\
\text { (at A I/T I) }(\%)\end{array}$ \\
\hline \multicolumn{5}{|l|}{ P. gracilis } \\
\hline P-1 60053 & $5.5(6 / 109)$ & $2.3(3 / 130)$ & $4.3(6 / 139)$ & $1.5(2 / 129)$ \\
\hline \multicolumn{5}{|l|}{ P. heterodonta } \\
\hline P-1 59664 & $24.6(31 / 126)$ & $19.1(25 / 131)$ & $5.4(6 / 110)$ & $0(0 / 129)$ \\
\hline P-2 60054 & $22.1(29 / 131)$ & $0.1(1 / 101)$ & $5.4(6 / 110)$ & $0(0 / 105)$ \\
\hline \multicolumn{5}{|l|}{ P. hoffmeisteri } \\
\hline P-1 58623 & $0(0 / 101)$ & $0(0 / 114)$ & $0(0 / 95)$ & $0(0 / 117)$ \\
\hline \multicolumn{5}{|l|}{ P. oederi } \\
\hline P-1 59502 & $11.3(1 / 97)$ & $5.5(5 / 90)$ & $7.2(7 / 97)$ & $2.1(2 / 97)$ \\
\hline P-2 60050 & $11.3(11 / 97)$ & $9.3(9 / 97)$ & $7.2(7 / 97)$ & $0(0 / 105)$ \\
\hline \multicolumn{5}{|l|}{$P$. pectinata } \\
\hline P-1 59784 & $0(0 / 110)$ & $0(0 / 104)$ & $3.0(3 / 100)$ & $1.8(2 / 109)$ \\
\hline P-2 60055 & $0(0 / 121)$ & $0(0 / 103)$ & $2.7(3 / 110)$ & $3.0(3 / 100)$ \\
\hline \multicolumn{5}{|l|}{ P. punctata } \\
\hline P-1 58622 & $0.9(1 / 107)$ & $0(0 / 111)$ & $3.6(4 / 111)$ & $2.7(3 / 109)$ \\
\hline
\end{tabular}

Figures in parenthesis denote observed number of abnormal PMCs in the numerator and total number of PMCs observed in the denominator.
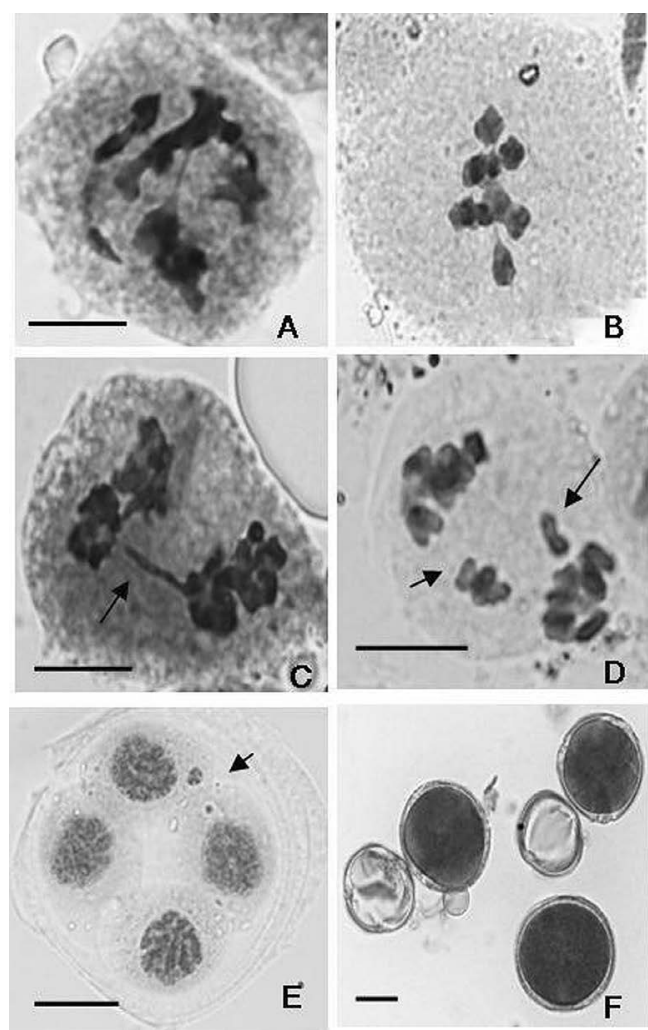

Fig. 2. PMC's with Interbivalent connections in $P$. gracilis and $P$. punctata, respectively (A, B), a PMC showing chromatin bridge in $P$. heterodonta (C), a PMC showing laggards in $P$. oederi (D), tetrad with micronucleus (E), heterogeneous sized pollen grains in $P$. punctata (F). Scale bars $=10 \mu \mathrm{m}$.

etc. by Levin (2002).

$P$. punctata reveals a diploid cytotype with $n=8$ (Fig. $1 \mathrm{~F})$, which is reported for the first time.

The chromosomal numbers reported in 122 Pedicularis species are ranging from $2 n=12$ to $2 n=36$ with a maximum frequent number of $2 n=16$ as the number is reported in 102 species (see Rice et al. 2015). The genus is monobasic on $x=8$. But, there are few reports on $x=6$, 7 and 15 , which need further investigations to clear evo- lution of basic number in the genus.

\section{Meiotic abnormalities}

Meiotic abnormalities viz. chromatin stickiness, unoriented bivalent, interbivalent connections (Fig. 2A, B), chromatin bridges (Fig. 2C), laggards, and abnormal microsporogenesis along with heterogeneity in the size of pollen grains have been reported in most of the studied populations (Table 2). P. heterodonta reveals the maximum frequency of un-oriented bivalents (Table 2), that arise due to impaired kinetochore attachment or late terminalization of chiasmata (Pagliarini 2000) and results in the laggards formation (Table 2, Fig. 2D), which might result into micronuclei (Fig. 2E) and un-even gametes. These laggards may further lead to heterogeneity in pollen grain size (Fig. 2F).

\section{Acknowledgements}

This work was supported by the University Grants Commission, New Delhi under UGC-BSR Fellowship scheme (award letter number 6007/04/04/2013) and IPLS-DBT (reference number: BT/PR 4548/INF/22/146/2012). Thanks are also due to Late Sh. Kishan Lal, who assisted the author with their intense field knowledge during the collection tours.

\section{References}

Amano, M. 1999. Cytotaxonomical study of Pedicularis (Spermatophyta; Scrophulariaceae) in Annapurna Himal, Nepal. Nat. Hist. Res. 5: 73-78.

Chu, H., Tan, N. and Peng, C. 2009. Progress in research on $\mathrm{Pe}$ dicularis plants. Zhongguo Zhong Yao Za Zhi 34: 2536-2546. (in Chinese)

Ganjhu, R. K., Mudgal, P. P., Maity, H., Dowarha, D., Devadiga, S., Nag, S. and Arunkumar, G. 2015. Herbal plants and plant preparations as remedial approach for viral diseases. Virus Dis. 26: 225-236.

Houben, A. 2017. B chromosomes-A matter of chromosome drive. 
Front. Plant Sci. 8: 210-226.

Khodaie, L., Delazar, A., Pour, F. L., Nazemiyeh, H., Asnaashari, S., Moghadam, S. B., Nahar, L. and Sarker, S. D. 2012. Phytochemistry and bioactivity of Pedicularis sibthorpii growing in Iran. Rev. Bras. Farmacogn. 22: 1268-1275.

Levin, D. A. 2002. The Role of Chromosomal Change in Plant Evolution. Oxford University Press, London.

Mehra, P. N. and Gill, L. S., 1968. IOPB chromosome number Reports XVIII. Taxon 17: 419-422.

Mura, Y. and Iwashina, T. 2015. Phenolic compounds in the leaves of Pedicularis chamissonis in Japan. Bull. Natl. Mus. Nat. Sci. Ser. B 41: 131-136.

Pagliarini, M. S. 2000. Meiotic behavior of economically important plant species: The relationship between fertility and male sterility. Genet. Mol. Res. 23: 997-1002.

Rice, A., Glick, L., Abadi, S., Einhorn, M., Kopelman, N. M., Minkov, A. S., Mayzel, J., Chay, O. and Mayrose, I. 2015. The Chromosome Counts Database (CCDB) - A community resource of plant chromosome number. New Phytol. 1: 19-26.

Saggoo, M. I. S. and Srivastava, D. K. 2009. Meiotic studies in some species of Pedicularis L. from cold desert regions of Himachal Pradesh, India (North-West Himalaya). Chromosome Bot. 4:
$83-86$.

Singh, V., Gupta, R. C. and Kaur, K. 2016. In: Marhold, K. and Kučera, J. (eds.). IAPT/IOPB chromosome data 21. Taxon $\mathbf{6 5}$ : 673-676.

Uhríková, A. and Dúbravcová, Z. 2000. Karyologické štúdium slovenskej flóry XXXI. Acta Fac. Rerum Nat. Univ. Comen. Bot. 40: $27-30$.

Yatoo, M. I., Dimri, U., Gopalakrishnan, A., Karthik, K., Gopi, M., Khandia, R., Saminathan, M., Saxena, A., Alagawany, M., Farag, M. R., Munjal, A. and Dhama, K. 2017. Beneficial health applications and medicinal values of Pedicularis plants: A review. Biomed. Pharmacother 95: 1301-1313.

Yatoo, M. I., Dimri, U., Gopalakrishan, A., Saminathan, M., Dhama, K., Mathesh, K., Saxena, A., Gopinath, D. and Husain, S. 2016. Antidiabetic and oxidative stress ameliorative potential of ethanolic extract of Pedicularis longiflora Rudolph. Int. J. Pharmacol. 12: 177-187.

Zhao, X., Han, F., Li, Y., Zhou, G. Y. and Yue, H. L. 2013. Semipreparative separation and purification of three flavonoids from Pedicularis longiflora var. tubiformis (Klotzsch) P. C. Tsoong by HSCCC. J. Liq. Chrom. Relat. Tech. 36: 1751-1761. 